\title{
Makrozoobentos sebagai bioindikator kualitas perairan Pulau Penyengat, Kepulauan Riau
}

\author{
Y. Rosdatina ${ }^{1}$, T. Apriadi ${ }^{*}$, W. R. Melani ${ }^{1}$ \\ ${ }^{1}$ Program Studi Manajemen Sumberdaya Perairan, Fakultas Ilmu Kelautan dan Perikanan, Universitas \\ Maritim Raja Ali Haji, Tanjungpinang, Indonesia
}

\begin{abstract}
Abstrak
Penelitian ini bertujuan untuk mengetahui kualitas perairan Pulau Penyengat, Kepulauan Riau, berdasarkan keberadaan makrozoobentos. Penentuan stasiun penelitian menggunakan metode purposive sampling, yang terdiri dari 5 stasiun yaitu: daerah pelabuhan, pemukiman penduduk, reklamasi, ekosistem mangrove dan tempat pembuangan sampah sementara. Pengukuran parameter fisika dan kimia perairan serta pengambilan sampel makrozoobentos dilakukan sebanyak 3 kali ulangan pada setiap stasiun. Analisis kualitas perairan berdasarkan makrozoobentos menggunakan indeks AMBI (A Marine Biotic Index). Hasil penelitian menggambarkan bahwa parameter fisika dan kimia perairan Pulau Penyengat masih memenuhi baku mutu. Makrozoobentos yang dijumpai sebanyak 14 spesies terdiri dari 6 kelas. Indeks keanekaragaman pada setiap stasiun tergolong rendah, indeks keseragaman tergolong sedang-tinggi, sedangkan indeks dominansi tergolong rendah. Berdasarkan indeks AMBI, perairan Pulau Penyengat tergolong tidak tercemar.
\end{abstract}

Kata kunci: bioindikator, indeks AMBI, makrozoobentos, Pulau Penyengat

\begin{abstract}
.
The objective of this study was to determine the water quality on Penyengat Island, Riau Islands, based on macrozoobenthos ecological index. Determination of research stations was by purposive sampling method. There were 5 sampling stations; ports area, residential areas, reclamation, mangrove ecosystem and temporary landfill. Physical and chemical parameters and macrozoobenthos were taken at each station by 3 repetitions. Macrozoobenthos as bioindicator water quality was analyzed by AMBI (A Marine Biotic Index). The results showed that water quality of Penyengat Island met quality standards. Macrozoobenthos were found as many as 14 species consisting of 6 classes. The diversity index value at each station was low, similarity index was medium to low, and dominance at all stations were low. Based on the category of AMBI index the waters of Penyengat Island in each station was classified as not polluted.
\end{abstract}

Keywords: bioindicators, AMBI index, macrozoobenthos, Penyengat Island

\section{PENDAHULUAN}

Pulau Penyengat terletak di Kelurahan Penyengat, Kecamatan Tanjungpinang Kota, Kota Tanjungpinang, Provinsi Kepulauan Riau yang mana Pulau Penyengat telah dikenal sebagai pulau tua bersejarah. Secara geografis wilayah Provinsi Kepulauan Riau terletak antara $0^{\circ} 40^{\circ} \mathrm{LS}$ dan $07^{\circ} 19^{\circ} \mathrm{LU}$ serta antara $103^{\circ} 30$ BT sampai dengan $110^{\circ} 00^{\circ}$ BT (Ramelan et al. 2017). Pulau Penyengat merupakan kawasan pesisir yang memiliki objek wisata yang tentunya memiliki aktivitas cukup padat seperti kawasan ekowisata, kegiatan transportasi laut, pembangunan taman wisata, tempat penampungan sementara (TPS) sampah dan aktivitas rumah tangga yang membuang limbah ke perairan.

Aktivitas masyarakat di sekitar pesisir pulau memegang andil dalam penurunan kualitas perairan. Penurunan kualitas perairan akan diikuti perubahan kondisi fisika, kimia dan biologis. Jika beban masukan bahan terlarut melebihi kapasitas maka timbul permasalahan yang serius yaitu pencemaran

\footnotetext{
${ }^{*}$ Korespondensi Penulis

Email : tri.apriadi@umrah.ac.id
} 
perairan yang akan berdampak pada penurunan keanekaragaman organisme termasuk makrozoobentos. Menurunnya kualitas perairan dapat diketahui dengan beberapa cara salah satunya dengan melihat keberadaan makrozoobentos di substratnya (Musthofa et al. 2014).

Makrozoobentos merupakan salah satu organisme akuatik yang menetap di dasar perairan, memiliki pergerakan relatif lambat dan dapat hidup relatif lama sehingga memiliki kemampuan untuk merespon kondisi kualitas perairan, serta sering dijadikan sebagai bioindikator (Zulkifli dan Setiawan 2011). Melihat adanya aktivitas yang berbeda di perairan Pulau Penyengat, maka peneliti melakukan kajian untuk mengetahui kualitas perairan Pulau Penyengat dengan menggunakan makrozoobentos sebagai bioindikator melalui perhitungan indeks ekologi makrozoobentos, indeks AMBI (A Marine Biotic Index), serta parameter fisika-kimia perairan.

\section{METODOLOGI}

\subsection{Lokasi dan waktu penelitian}

Penelitian ini dilaksanakan pada bulan Februari-Maret 2019. Pengambilan sampel dilakukan di Perairan Pulau Penyengat, Kepulauan Riau. Penentuan lokasi sampling (stasiun) menggunakan metode purposive sampling berdasarkan pertimbangan tingkat aktivitas yang ada di Pulau Penyengat (Gambar 1).

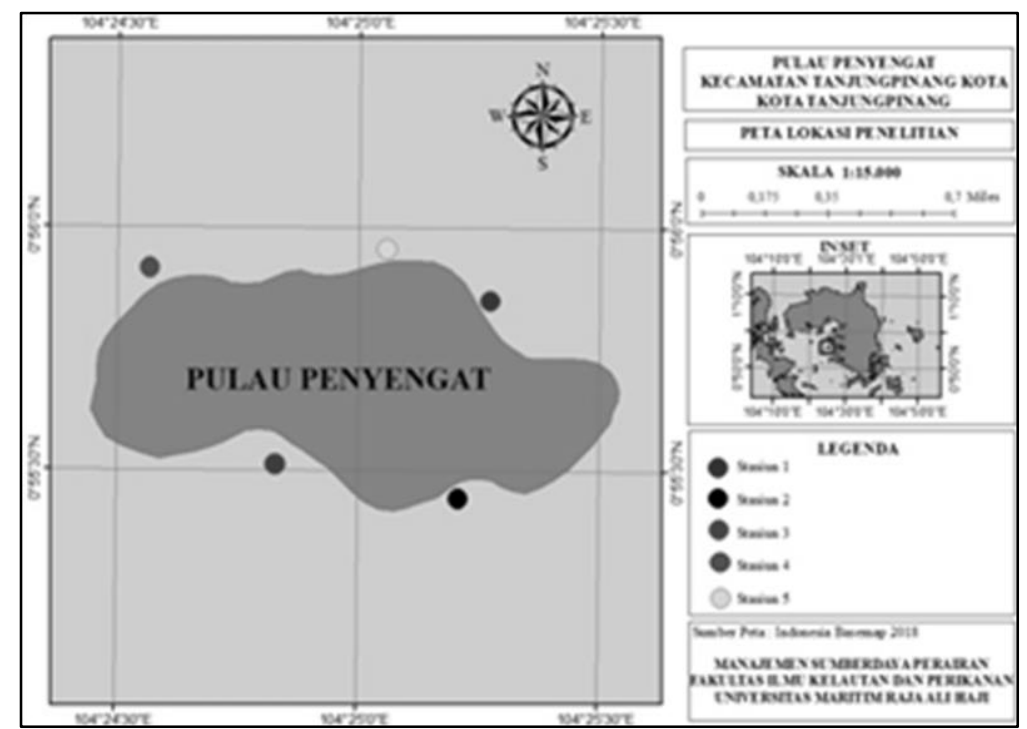

Gambar 1. Lokasi penelitian.

Pengambilan sampel dilakukan pada 5 stasiun. Stasiun 1 berada di daerah pelabuhan tempat transportasi laut antara Pulau Penyengat dengan Tanjungpinang. Stasiun 2 berada di pemukiman penduduk yang sebagian besar 
aktivitas masyarakatnya berhubungan dengan laut, baik memanfaatkan hasil laut untuk kehidupan sehari-hari maupun membuang limbah. Stasiun 3 berada di depan Balai Adat yaitu tempat pembangunan taman (reklamasi). Stasiun 4 merupakan ekosistem mangrove yang masih cukup alami. Stasiun 5 merupakan TPS sampah seluruh masyarakat Pulau Penyengat, tepatnya di Kampung Bulang.

\subsection{Alat dan bahan}

Alat yang digunakan dalam penelitian ini adalah multitester, GPS, refraktometer, turbidimeter, mikroskop stereo, ayakan dengan mata saring 1 $\mathrm{mm}$, ekman grab dan oven. Bahan yang digunakan adalah rose bengal dan alkohol 70\% untuk mengawetkan biota (APHA 2012).

\subsection{Pengambilan dan penanganan sampel}

Pengambilan sampel makrozoobentos menggunakan ekman grab ukuran $30 \times 30 \mathrm{~cm}\left(900 \mathrm{~cm}^{2}\right)$. Sampel makrozoobentos yang telah didapat kemudian disaring menggunakan ayakan. Setelah diperoleh, bentos dicuci dengan air tawar agar bersih, lalu dimasukkan ke dalam kantong sampel dan diberi larutan alkohol $70 \%$ dan rose bengal untuk pengawetan. Makrozoobentos kemudian diamati menggunakan mikroskop stereo di Laboratorium Marine Biology, Fakultas Ilmu Kelautan dan Perikanan, Universitas Maritim Raja Ali Haji.

\subsection{Analisis data}

Analisis makrozoobentos meliputi identifikasi makrozoobentos, kepadatan makrozoobentos, indeks keanekaragaman ( $\left.\mathrm{H}^{\prime}\right)$, indeks keseragaman (E), indeks dominansi (C) dan indeks AMBI. Data hasil analisis disajikan dalam bentuk tabel dan grafik. Analisis makrozoobentos dilakukan dengan menggunakan Persamaan 1-5.

1. Kepadatan Populasi (Fachrul 2007; Brower et al. 1990 dalam Hafshah et al. 2012)

$$
\mathrm{K}=\frac{10000 \times \mathrm{a}}{\mathrm{b}} \text {. }
$$

Keterangan : $\mathrm{K}=$ Kepadatan makrozoobentos

$a=$ Jumlah makrozoobentos

$b=$ Luas bukaan grab $\left(\mathrm{cm}^{2}\right)$

$10000=$ Konversi dari $\mathrm{cm}^{2} \mathrm{ke} \mathrm{m}^{2}$

2. Indeks Keanekaragaman (Odum 1993; Krebs 2014)

$\mathrm{H}^{\prime}=-\sum$ pi Ln pi

Keterangan : $\mathrm{H}^{\prime}$ = Indeks Keanekaragaman Shannon-Wiener

$\mathrm{Pi}=$ Proporsi spesies ke-i (ni/N) 
3. Indeks Keseragaman (Odum 1993; Krebs 2014)

$$
\begin{aligned}
& \mathrm{E}^{\prime}=\frac{\mathrm{H}^{\prime}}{\mathrm{H}^{\prime} \text { maks }} \\
& \text { Keterangan : } \begin{aligned}
& \mathrm{E}^{\prime}=\text { Indeks Keseragaman } \\
& \mathrm{H}^{\prime}=\text { Indeks Keanekaragaman Shannon-Wiener } \\
& \mathrm{H}^{\prime} \text { Maks }=\ln \mathrm{S}(\mathrm{S}=\text { jumlah spesies })
\end{aligned}
\end{aligned}
$$

4. Indeks Dominansi (Odum 1993; Krebs 2014)

$$
\mathrm{C}=\Sigma(\mathrm{pi})^{2}
$$

Keterangan : $\mathrm{C}=$ Indeks dominansi

pi = proporsi spesies ke-i (ni/N)

5. Indeks AMBI (A Marine Biotic Index) (Borja et al. 2000)

$$
\begin{aligned}
& \text { AMBI }=\{(0 \times \% G I)+(1,5 \times \% G I I)+(3 \times \% G I I I)+(4,5 \times \% G I V)+(6 \times \% G V)\} / 100 \\
& \text { Keterangan : } \\
& \text { (G I) kelompok "Spesies sensitif" } \\
& \text { (G II) kelompok "Spesies indefferent" } \\
& \text { (G III) kelompok "Spesies toleran". } \\
& \text { (G IV) kelompok "Spesies oportunistik urutan kedua } \\
& \text { (G V) kelompok "Spesies oportunistik orde 1" }
\end{aligned}
$$

Parameter kualitas (fisik-kimia) perairan dianalisis menurut KepMenLH Nomor 51 Tahun 2004 tentang Baku Mutu Air Laut untuk batas atau kadar kehidupan makrozoobentos di perairan Pulau Penyengat.

\section{HASIL DAN PEMBAHASAN}

\subsection{Kualitas perairan Pulau Penyengat}

Secara umum berdasarkan baku mutu perairan KepMenLH Nomor 51 Tahun 2004, perairan Pulau Penyengat masih tergolong baik yang mampu mendukung kehidupan makrozoobentos. Tipe substrat yang dijumpai di perairan Pulau Penyengat yaitu pasir berkerikil dan kerikil berpasir. Substrat merupakan salah satu faktor yang sangat memengaruhi kehidupan, perkembangan dan keragaman makrozoobentos. Hasil pengukuran parameter fisik-kimia di perairan Pulau Penyengat disajikan pada Tabel 1.

Menurut Nuraccmi (2012) dalam Choirudin et al. (2014), makrozoobentos erat kaitannya dengan ketersediaan bahan organik dalam substrat, karena bahan organik yang umumnya terdapat pada substrat dasar merupakan sumber nutrien bagi biota. Bahan organik sangat berpengaruh terhadap kelimpahan makrozoobentos, baik secara langsung maupun tidak. Namun, tingginya kandungan bahan organik tidak selamanya menguntungkan bagi organisme dasar perairan, karena dapat menyumbat alat pernafasan (Ulfah et al. 2012). 
Tabel 1. Kualitas perairan Pulau Penyengat.

\begin{tabular}{lcrrrrc}
\hline \multicolumn{1}{c}{ Parameter } & Stasiun 1 & Stasiun 2 & Stasiun 3 & Stasiun 4 & Stasiun 5 & $\begin{array}{c}\text { Baku } \\
\text { Mutu* }\end{array}$ \\
\hline Suhu $\left({ }^{\circ} \mathrm{C}\right)$ & $30,00 \pm 0,2$ & $30,00 \pm 0,3$ & $30,30 \pm 0,2$ & $30,20 \pm 1,00$ & $30,00 \pm 0,76$ & $\begin{array}{c}\text { Alami } \\
\text { Kekeruhan (NTU) }\end{array}$ \\
Kecepatan arus & $0,92 \pm 0,17$ & $1,67 \pm 1,15$ & $1,00 \pm 0,25$ & $0,73 \pm 0,37$ & $1,27 \pm 0,68$ & $<5 \mathrm{NTU}$ \\
(m/detik) & & $0,26 \pm 0,03$ & $0,04 \pm 0,01$ & $0,04 \pm 0,01$ & $0,05 \pm 0,01$ & - \\
Salinitas (psu) & $32,00 \pm 0,00$ & $32,00 \pm 0,00$ & $32,00 \pm 0,00$ & $32,00 \pm 0,00$ & $32,00 \pm 0,00$ & Alami \\
pH & $7,52 \pm 0,54$ & $7,52 \pm 0,44$ & $7,55 \pm 0,44$ & $7,65 \pm 0,39$ & $7,62 \pm 0,42$ & $7-8,5$ \\
DO (mg/L) & $7,20 \pm 0,15$ & $7,34 \pm 0,11$ & $7,13 \pm 0,14$ & $7,06 \pm 0,21$ & $7,11 \pm 0,14$ & $>5 \mathrm{mg} / \mathrm{L}$ \\
TOM (mg/L) & $9,60 \pm 0,02$ & $13,60 \pm 0,02$ & $11,60 \pm 0,03$ & $8,00 \pm 0,01$ & $7,00 \pm 0,02$ & - \\
Substrat & Pasir & Kerikil & Pasir & Pasir & Kerikil & - \\
\hline
\end{tabular}

Keterangan : *Baku mutu berdasarkan KepMenLH Nomor 51 Tahun 2004.

\subsection{Kepadatan dan komposisi makrozoobentos}

Berdasarkan hasil identifikasi makrozoobentos, di perairan Pulau Penyengat ditemukan 4 filum makrozoobentos yang terdiri dari 6 kelas dan 14 genera. Keempat filum tersebut adalah mollusca, annelida, arthropoda, echinodermata. Sementara enam kelas yang ditemukan adalah gastropoda, bivalvia, chepapoda, clitellata, malacostraca dan echinodermata (Tabel 2).

Kepadatan makrozoobentos tertinggi terdapat pada stasiun 2 sebanyak $139 \mathrm{ind} / \mathrm{m}^{2}$ dan terendah pada stasiun 4 sebanyak $42 \mathrm{ind} / \mathrm{m}^{2}$. Tingginya nilai kepadatan pada stasiun 2 diduga karena lokasi tersebut merupakan daerah pemukiman penduduk yang memiliki masukan bahan organik tinggi dibandingkan lokasi lainnya. Kondisi fisik-kimia lingkungan perairan memengaruhi kepadatan, komposisi dan tingkat keragaman makrozoobentos (Ulfah et al. 2012). Kepadatan makrozoobentos yang didapatkan selama penelitian secara lengkap tersaji pada Tabel 2.

Tabel 2. Kepadatan makrozoobentos.

\begin{tabular}{llccccc}
\hline \multirow{2}{*}{ Filum } & \multirow{2}{*}{ Jenis } & \multicolumn{5}{c}{ Kepadatan (ind $/ \mathrm{m}^{2}$ ) } \\
\cline { 3 - 7 } Mollusca & Cerithideopsis & 55 & St. 2 & St. 3 & St. 4 & St. 5 \\
& Littorina & - & - & - & 1 & 47 \\
& Clypeomorus & 21 & 11 & - & - & - \\
& Batillaria & 11 & - & 20 & - & 19 \\
& Litiopa & - & - & 18 & - & - \\
& Clavigera & - & 15 & - & 11 & - \\
& Pirenella & - & 15 & - & - & - \\
& Thiara & 6 & - & - & 14 & - \\
& Neotrigonia & - & 14 & - & - & 20 \\
& Tellina & 6 & - & - & 9 & - \\
& Spirula & - & 1 & - & - & - \\
& \multicolumn{1}{c}{ Total Mollusca } & 100 & 131 & 68 & 35 & 86 \\
\hline
\end{tabular}




\begin{tabular}{|c|c|c|c|c|c|c|}
\hline \multirow{2}{*}{ Filum } & \multirow{2}{*}{ Jenis } & \multicolumn{5}{|c|}{ Kepadatan (ind $/ \mathrm{m}^{2}$ ) } \\
\hline & & St. 1 & St. 2 & St. 3 & St. 4 & St. 5 \\
\hline \multirow[t]{2}{*}{ Annelida } & Clitellio & - & 8 & - & - & 11 \\
\hline & Total Annelida & - & 8 & - & - & 11 \\
\hline \multirow{2}{*}{ Arthropoda } & Litopenaeus & - & - & - & 1 & - \\
\hline & Total Arthropoda & - & - & - & 1 & - \\
\hline \multirow[t]{3}{*}{ Echinodermata } & Echinus & - & - & 7 & 6 & - \\
\hline & Total Echinodermata & - & - & 7 & 6 & - \\
\hline & TOTAL & 100 & 139 & 75 & 42 & 97 \\
\hline
\end{tabular}

Hasil analisis komposisi makrozoobentos pada tingkat filum menunjukkan adanya perbedaan komposisi penyusunan komunitas pada seluruh lokasi. Pada stasiun 1 hanya ditemukan kelas mollusca, stasiun 2 terdapat kelas mollusca dan annelida, stasiun 3 terdiri dari kelas mollusca dan echinodermata, stasiun 4 terdiri dari kelas mollusca, arthropoda dan echinodermata, sedangkan stasiun 5 terdapat kelas mollusca dan annelida. Gambaran persentase komposisi makrozoobentos di seluruh lokasi penelitian tersaji pada Gambar 2.

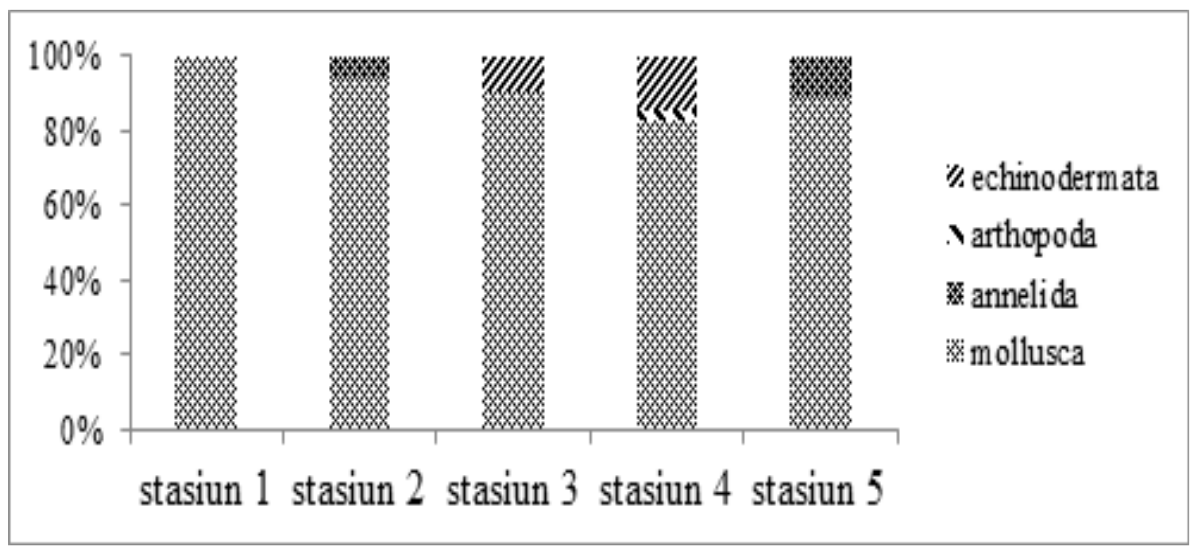

Gambar 2. Komposisi makrozoobentos berdasarkan filum.

Pada semua lokasi ditemukan filum mollusca, yaitu stasiun 1-5 dengan nilai persentase yang tinggi. Mollusca yang memiliki sifat bisa bertahan di berbagai kondisi perairan yang baik maupun tidak, sehingga di semua stasiun ditemukan mollusca. Pada stasiun 2 yaitu daerah pemukiman penduduk dan stasiun 5 daerah TPS (tempat penampungan sementara) ditemukan filum annelida karena filum annelida bisa ditemukan pada perairan yang tercemar. Berbeda dengan echinodermata yang hanya di temukan di stasiun 3 dan 4, secara umum echinodermata lebih banyak dijumpai pada perairan yang jernih dan tenang (Radjab et al. 2014 dalam Sese et al. 2018).

Stasiun 3 dan 4 memiliki kecepatan arus lebih tenang dan kekeruhan yang lebih rendah dibandingkan stasiun lainnya. Filum arthropoda hanya ditemukan pada stasiun 4 yaitu daerah ekosistem mangrove karena arthropoda cukup 
rentan terhadap gangguan komunitas dibandingkan pada stasiun 1, 2, 3 dan 5 yang ada aktivitas dan bisa memengaruhi keberadaan arthropoda.

\subsection{Indeks ekologi makrozoobentos}

Keanekaragaman makrozoobentos di perairan Pulau Penyengat tergolong rendah (sedikit) dengan nilai indeks keanekaragaman <2,30 (1,23-1,50). Sedikitnya jenis yang ditemukan diduga karena pengaruh aktivitas masyarakat yang mencari siput dan kerang. Hasil perhitungan indeks ekologi makrozoobentos disajikan pada Tabel 3.

Tabel 3. Indeks ekologi makrozoobentos.

\begin{tabular}{lccccc}
\hline \multirow{2}{*}{ Indeks } & \multicolumn{5}{c}{ Nilai Indeks } \\
\cline { 2 - 6 } & Stasiun 1 & Stasiun 2 & Stasiun 3 & Stasiun 4 & Stasiun 5 \\
\hline Keanekaragaman (H') & 1,23 & 1,44 & 1,28 & 1,50 & 1,24 \\
Keseragaman (E) & (Rendah) & (Rendah) & (Rendah) & (Rendah) & (Rendah) \\
& 0,77 & 0,74 & 0,92 & 0,83 & 0,89 \\
Dominansi (C) & (Tinggi) & (Sedang) & $($ Tinggi) & (Tinggi) & (Tinggi) \\
& 0,37 & 0,33 & 0,29 & 0,30 & 0,32 \\
& (Rendah) & (Rendah) & (Rendah) & (Rendah) & (Rendah) \\
\hline
\end{tabular}

Indeks keseragaman di perairan Pulau Penyengat pada stasiun 1, 3, 4 dan 5 tergolong tinggi dengan nilai mendekati maksimum $(1,00)$. Tingginya indeks keseragaman menggambarkan penyebaran populasi makrozoobentos cukup baik. Stasiun 2 memiliki indeks keseragaman sedang, yang menggambarkan kondisi makrozoobentos masih rentan dari gangguan komunitas.

Nilai keseragaman berbanding terbalik dengan nilai dominansi. Nilai indeks dominansi di seluruh lokasi penelitian umumnya mendekati 0 , artinya dominansi rendah atau tidak ada jenis tertentu yang mendominansi. Namun demikian, pada stasiun penelitian dijumpai jenis tertentu yang memiliki jumlah individu lebih banyak. Berdasarkan indeks ekologi, perairan Pulau Penyengat masih tergolong perairan yang baik karena tidak ada jenis yang mendominasi.

\subsection{Indeks AMBI (a marine biotic index)}

Masing-masing spesies makrozoobentos memiliki indikator terhadap pencemaran yakni bersifat fakultatif, toleran dan intoleran. Kelompok gastropoda jenis Cerithideopsis sp. dan Batillaria sp. sering ditemukan hampir di setiap stasiun, mulai dari stasiun dengan kondisi lingkungan baik sampai dengan kondisi kualitas air menurun. Kedua jenis makrozoobentos tersebut digolongkan ke dalam kriteria spesies fakultatif karena mempunyai kisaran hidup yang luas, serta dapat bertahan pada perairan yang mengandung bahan organik tinggi dan bahan pencemar pada tingkat tertentu.

Indeks AMBI digunakan untuk mengetahui nilai sensitivitas makrozoobentos. Nilai sensitivitas makrozoobentos di perairan Pulau 
Penyengat untuk klasifikasi polusi masuk dalam kategori tidak tercemar, dengan komunitas bentik yang masih normal (Tabel 4). Jumlah makrozoobentos toleran yang ditemui relatif sedikit yang artinya perairan Pulau Penyengat masih baik dan mampu mendukung untuk kehidupan biota.

Tabel 4. Nilai indeks AMBI.

\begin{tabular}{cccccc}
\hline Indeks & Stasiun 1 & Stasiun 2 & Stasiun 3 & Stasiun 4 & Stasiun 5 \\
\hline \multirow{3}{*}{ AMBI } & 0,015 & 0,017 & 0,018 & 0,017 & 0,018 \\
& (tidak & $\begin{array}{c}\text { (tidak } \\
\text { tercemar) }\end{array}$ & $\begin{array}{c}\text { (tidak } \\
\text { tercemar) }\end{array}$ & $\begin{array}{c}\text { (tidak } \\
\text { tercemar) }\end{array}$ & $\begin{array}{c}\text { (tidak } \\
\text { tercemar) }\end{array}$ \\
\hline
\end{tabular}

\section{KESIMPULAN DAN SARAN}

Kualitas perairan Pulau Penyengat berdasarkan fisika-kimia perairan pada setiap stasiun masih memenuhi baku mutu untuk mendukung kehidupan makrozoobentos. Perhitungan indeks ekologi diketahui bahwa spesies makrozoobentos pada perairan Pulau Penyengat masih tergolong rendah dengan kondisi makrozoobentos yang belum merata. Nilai indeks keanekaragaman di seluruh stasiun (rendah), keseragaman pada stasiun 1, 3, 4, 5 (tinggi) dan stasiun 2 (sedang), serta dominansi pada seluruh stasiun (rendah). Perairan Pulau Penyengat berdasarkan indeks AMBI tergolong tidak tercemar.

\section{DAFTAR PUSTAKA}

[APHA] American Public Health Association. 2012. Standard methods for the examination of water and wastewater 22nd edition. American Public Health Association. Virginia.

Borja A, Franco J and Perez V. 2000. A marine biotic index to establish the ecological quality of soft-bottom benthos within European estuarine and coastal environments. Marine Pollution Bulletin 40(12):1114-2000.

Choirudin IR, Supardjo MN dan Muskananfola MR. 2014. Studi hubungan kandungan bahan organik sedimen dengan kelimpahan makrozoobentos di Muara Sungai Wedung Kabupaten Demak. Diponegoro Jurnal of Maquares 3(3):168-176.

Fachrul MF. 2007. Metode sampling bioekologi. Bumi Aksara. Jakarta Hafshah GI, Suherman H dan Mulyani Y. 2012. Hubungan limbah organik dengan struktur komunitas makrozoobentos di Sungai Musi Bagian Hilir. Jurnal Perikanan dan Kelautan 3(3):25-31.

Musthofa A, Muskananfola MR dan Rudiyanti S. 2014. Analisis struktur komunitas makrozoobenthos sebagai bioindikator kualitas perairan Sungai Wedung Kabupaten Demak. Diponegoro Jurnal of Maquares 3(1):81-88. 
KepMenLH (Keputusan Menteri Negara Lingkungan Hidup) Nomor 51 Tahun 2004 tentang baku mutu air laut.

Krebs CJ. 2014. Species diversity measures, version 5. Addison Wesley Longman, Inc. New York.

Odum EP. 1993 Dasar-dasar ekologi. Diterjemahkan oleh : Samingan T. UGM Press. Yogyakarta.

Ramelan WDS, Oesma 0, Ghautama G, Rahardjo S dan Widion P. 2017. Konsep zonasi Pulau Penyengat: sebuah alternatif. Jurnal Penelitian dan Pengembangan Arkeologi 35(1):1-74.

Sese MR, Annawaty dan Yusron E. 2018. Keanekaragaman echinodermata (echinoidea dan holothuroidea) di Pulau Bakalan, Banggai Kepulauan, Sulawesi Tengah, Indonesia. Scripta Biologica 5(2):73-77.

Ulfah Y, Widianingsih dan Zainuri M. 2012. Struktur komunitas di perairan wilayah Morosari Desa Bedono, Kecamatan Sayung Demak. Journal of Marine Research 1(2):188-196.

Zulkifli H dan Setiawan D. 2011. Struktur dan fungsi komunitas makrozoobentos di perairan Sungai Musi Kawasan Pulokerto sebagai Instrumen Biomonitoring. Jurnal Natur Indonesia 14(1):95-99. 